\title{
EFEKTIFITAS PEMBERIAN PROBIOTIK TERHADAP DURASI DIARE ANAK DI RUMAH SAKIT PKU MUHAMMADIYAH BANTUL YOGYAKARTA
}

\section{EFFECTIVENESS OF PROBIOTICS GIVING FOR THE CHILDREN'S DIARRHEA DURATION IN PKU MUHAMMADIYAH BANTUL HOSPITAL YOGYAKARTA}

\author{
Sri Mulyani ${ }^{1}$, Dyah Aryani $\mathbf{P}^{\mathbf{1}}$, Nurcholid Umam $^{\mathbf{2}}$ \\ ${ }^{1}$ Program Pascasarjana Farmasi Klinik Universitas Ahmad Dahlan Yogyakarta \\ ${ }^{2}$ RSU PKU Muhammadiyah Bantul, Yogyakarta \\ Jl. Jend. Sudirman 12, Bantul, Yogyakarta \\ Email: yanisoedarso29@gmail.com
}

Submitted: 12-09-2015

Reviewed: 15-09-2015

Accepted:11-05-2016

\begin{abstract}
ABSTRAK
Diare merupakan penyebab kematian utama kedua pada anak-anak di dunia, demikian juga di Indonesia. Untuk menurunkan kematian karena diare perlu tata laksana yang cepat dan tepat. Probiotik sudah digunakan secara luas pada kasus diare akut pada anak namun belum direkomendasikan oleh World Health Organization (WHO). Penelitian ini bertujuan untuk mengetahui pola pemberian terapi diare pada anak di RSU PKU Muhammadiyah Bantul dan mengetahui suplementasi probiotik pada terapi standar memberikan hasil penurunan durasi diare yang lebih baik dibandingkan hanya dengan terapi standar dalam tata laksana diare akut pada anak-anak.

Penelitian ini dilaksanakan dengan rancangan kohort retrospektif menggunakan data rekam medis dengan diagnosa diare akut atau gastroenteritis akut (GEA, ICD A09), antara bulan Januari-Desember 2014 di bangsal anak RSU PKU Muhammadyah Bantul Yogyakarta. Data dibagi menjadi 3 kelompok. Kelompok I yang mendapatkan terapi standar rehidrasi dan zink. Kelompok II yang mendapatkan terapi rehidrasi, zink dan probiotik. Kelompok III yang mendapatkan terapi rehidrasi dan probiotik. Data durasi diare sebagai luaran efektifitas probiotik dianalisis secara statistik untuk mengetahui perbedaan luaran antar kelompok.

Dari ketiga kelompok, kelompok I, kelompok II dan kelompok III diperoleh rata-rata durasi diare masing-masing adalah 66,33 (SD 21,66) jam, 55,32 (SD 19,07) jam dan 54,79 (SD 17,69) jam. Hasil uji statistik anova dari ketiga kelompok menunjukkan perbedaan yang bermakna $(\mathrm{p}=0,014)$. Hasil uji t kedua kelompok probiotik (II dan III) terhadap kelompok kontrol adalah berbeda bermakna dengan nilai $\mathrm{p}$ masing-masing 0,018 dan 0,011, sedangkan kelompok II dan kelompok III tidak berbeda bermakna $(\mathrm{p}=0,898)$.

Pola terapi diare pada RSU PKU Muhammadyah Bantul Yogyakarta terbagi menjadi 3 macam terapi utama.Yang pertama terapi rehidrasi dan suplementasi zink, kedua terapi rehidrasi dan suplementasi zink dan probiotik, yang ketiga adalah terapi rehidrasi dan suplementasi probiotik. Suplementasi probiotik terbukti efektif mengurangi durasi diare secara bermakna dibandingkan pasien yang mendapatkan terapi standar.
\end{abstract}

Kata kunci: diare akut, zink, probiotik, durasi diare

\section{ABSTRACT}

Diarrhea is the second leading cause of children's death worldwide, including in Indonesia.With regard to reducing the number of death, it is highly needed to provide a quick and accurate treatment. In clinical practice, prebiotics has been widely used as a treatment, particularly in 
the case of acute diarrhea in children. However, it is still not recommended by WHO. This study is aimed to determine the treatment pattern of diarrhea in children's ward at PKU Muhammadiyah Bantul Hospital and determine whether probiotic supplementation on standard therapy results a decrease in the duration of diarrhea which is better than only the standard therapy in the management of acute diarrhea in children.

This study used retrospective cohort design using data from medical records with diagnose acute diarrhea or acute gastroenteritis (ICD A09). The data was collected from January to December 2014, at children'2 ward, PKU Muhammadiyah Bantul Hospital, Yogyakarta. Data was divided into three groups: (i) Group I those who were treated by using standard therapeutic with rehydration and zinc, (ii). Group II those who were treated by combination of rehydration, zinc and probiotics, (iii) Group III those who were treated with rehydration and probiotics. Data duration of diarrhea as an outcome of the effectiveness of probiotics analyzed statistically to determine differences in outcomes between groups.

Among the three groups, Group I, Group II and group III gained an average duration of diarrhea 66.33 (SD 21.66) hours, 55.32 (SD 19.07) hours and 54.79 (SD 17.69) hours, respectively. The statistical test shows that there is significant different from diarrhea duration among the three groups $(\mathrm{p}=0.014)$. The test results between probiotic groups (II and III) and the control group is significantly different with p-value 0.018 and 0.011 , respectively. While the group II and group III do not differ significantly $(\mathrm{p}=0.898)$.

Treatment pattern therapy of diarrhea in PKU Muhammadiyah Bantul Hospital divided into three kinds of therapy. The first is rehydration therapy and zinc supplementation, the second is rehydration therapy and zinc supplementation and probiotics, the third is rehydration therapy and probiotics. Probiotic supplementation is proven effective in reducing the duration of diarrhea significantly compared to patients who were received standard therapy.

Keywords: acute diarrhea, zinc, probiotics, diarrhea duration

\section{PENDAHULUAN}

Diare merupakan penyebab utama kematian anak-anak nomor dua yaitu 9\% dari semua kematian anak di bawah usia 5 tahun di seluruh dunia. Pada tahun 2013, ini berarti 1.600 anak-anak meninggal setiap hari, atau sekitar 580.000 anak per tahun. Dari tahun 2000 hingga 2013, jumlah tahunan total kematian akibat diare di kalangan anak-anak di bawah 5 tahun menurun lebih dari 50 persen, dari lebih dari 1,2 juta menjadi kurang dari 0,6 juta (UNICEF, 2014). Penyebab utama kematian akibat diare adalah tata laksana yang tidak tepat baik di rumah maupun di sarana kesehatan. Untuk menurunkan kematian karena diare perlu tata laksana yang cepat dan tepat (Anonim, 2011). Terapi baku pada diare akut sesuai pedoman joint statement antara WHO dan UNICEF dalam manajemen klinik diare akut adalah pemberian cairan rehidrasi (oral dan parenteral), pemberian seng selama 10-14 hari serta meneruskan pemberian dietetik (WHO, 2004). Probiotik sudah digunakan secara luas pada kasus diare akut pada anak meskipun belum direkomendasikan oleh WHO (Anonim, 2011). Akhir-akhir ini penggunaan probiotik mulai diperkenalkan untuk mengatasi masalah diare di Indonesia. Penyakit menular yang selalu masuk dalam sepuluh besar penyakit (Puskesmas) selama beberapa tahun terakhir adalah diare. Angka kesakitan diare pada tahun 2013 sebesar 214 per 1000 penduduk dan dilaporkan bahwa 100\% balita yang menderita diare sudah ditangani (Anonim, 2014a). RSU PKU Muhammadiyah Bantul adalah salah satu rumah sakit di Kabupaten Bantul. Kabupaten Bantul merupakan daerah di Yogyakarta selatan, dimana diare masih menduduki 10 penyakit terbesar di rumah sakit pada umumnya. Diare di RSU PKU Bantul menempati urutan ke -2 dalam 10 besar penyakit dengan nilai prevalensi 14,5\% pada tahun 2014 (Anonim, 2014b). Belum ada penelitian tentang pola pemberian terapi diare pada anak dan efektifitas suplementasi probiotik pada diare anak di RSU PKU Muhammadiyah Bantul.

Menurut WHO, diare didefinisikan sebagai keadaan dimana seseorang mengalami mencret atau $\mathrm{BAB}$ cair sebanyak tiga kali sehari atau lebih, atau mengalami frekwensi BAB yang lebih dari biasanya (WHO, 2013). Diare akut menurut World Gastroenterology Organisation (WGO) didefinisikan sebagai keluarnya kotoran semi padat atau cair dari dalam usus dengan frekwensi 
abnormal yang berlangsung kurang dari 14 hari dan bila berlangsung lebih dari 14 hari disebut diare persisten (WGO, 2012).

Probiotik didefinisikan sebagai mikroorganisme hidup yang bila diberikan dalam jumlah adekuat dapat memberikan dampak positif bagi kesehatan pejamu (WGO, 2008). Probiotik berperan sebagai strain non patogenik dari organisme yang dimasukkan ke dalam diet untuk memodifikasi mikroba di usus, menyebabkan perubahan struktural (ekologi usus) dan fungsional (ekologi usus) yang menguntungkan dalam usus. Beberapa probiotik dapat menjadi penghalang bagi kolonisasi mikro organisme patogen untuk mencegah penyakit dan meningkatkan sistem kekebalan tubuh. Selain itu, beberapa probiotik mungkin mempunyai fungsi metabolisme seperti membantu fermentasi serat yang tidak dicerna, dan menyimpan energi dalam bentuk asam lemak rantai pendek. Dari semua jenis mikrobiota usus, Bifidobacteria dan Lactobacilli dianggap dua bakteri yang paling penting bermanfaat bagi kesehatan manusia sementara Staphylococcus dan Clostridia dianggap patogen bagi kesehatan manusia (Penders et.al., 2006).

\section{METODE PENELITIAN}

Desain Penelitian. Rancangan penelitian observasional dengan rancangan kohort retrospektif menggunakan data rekam medis selama tahun 2014.

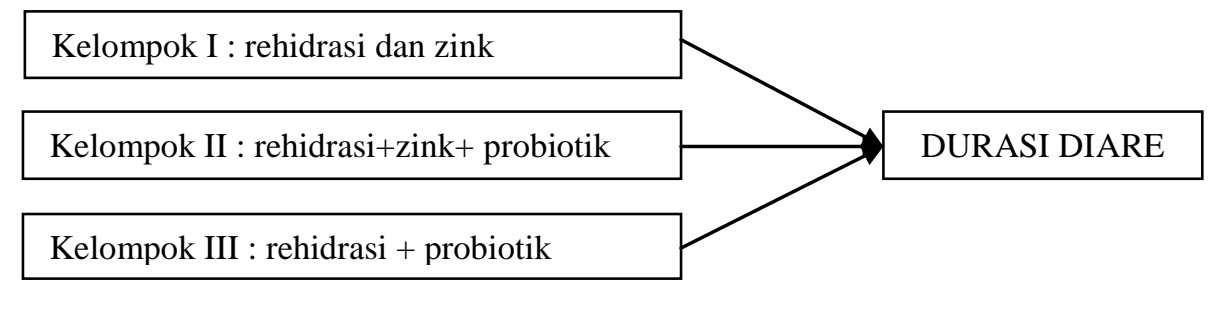

Tahun 2014

Luaran tahun 2014

\section{Gambar 1. Skema desain dan alur penelitian kohort retrospective dalam tahun 2014}

\section{Populasi}

1. Kriteria inklusi

a. Pasien anak 1 bulan sampai 5 tahun dengan jaminan kesehatan maupun umum ICD no. A09.

b. Dengan diagnose gastroenteritis akut ( ICD no. A09)

c. Mendapatkan terapi pada rawat inap

d. Tidak ada komorbid penyakit kronis yang menyebabkan rawat inap.

2. Kriteria eksklusi

a. Pasien anak dengan diare rawat jalan

b. Pasien anak dengan diare yang disebabkan oleh kanker saluran pencernaan, inflammatory bowel syndrome

c. Pasien diare anak disentri dan diare yang persistent

3. Besar sampel

Jumlah sampel ditentukan berdasarkan perbedaan rata-rata durasi diarenya, antara kontrol dan perlakuan dari penelitian-penelitian sebelumnya (Alasiry et.al., 2007; Hatta et.al., 2011; Aggarwal et.al., 2014), dihitung menggunakan besar sampel pada open epi.com (Dean et.al., 2011), didapatkan jumlah sampel untuk masing-masing kelompok 40.

\section{Pengumpulan data penelitian}

Pengumpulan data dilakukan observasi penelitian data pasien (rekam medik) yang diare antara bulan Januari 2014 sampai dengan Desember 2014. Dicatat usia, berat badan dan durasi diare pasien. Durasi diare adalah lamanya pasien menderita diare dalam satuan jam, terhitung sejak masuk rumah sakit dengan diagnosa GEA (ICD A09) jenis diare cair akut, mendapatkan terapi dan dinyatakan 
diarenya berhenti oleh dokter dan dari hasil pelaporan observasi perawat dalam perkembangan diarenya.

\section{Analisis data}

Data durasi diare dalam bentuk jam yang diperoleh dari masing-masing kelompok (40 sampel dari masing-masing kelompok) diuji statistik menggunakan analysis of variance (anova).

\section{HASIL DAN PEMBAHASAN}

Dari pengumpulan data penelitian ini, dalam tahun 2014 terdapat 339 kasus diare dengan ICD A09. Dari 339 yang termasuk kriteria ekslusi 34 kasus, dengan perincian 1 anak meninggal dunia akibat dehidrasi berat, 1 anak dirujuk ke rumah sakit pendidikan karena komorbid anemia berat dan 32 anak berusia di atas 5 tahun. Kasus yang termasuk dalam kriteria inklusi didapatkan 305 anak yang dirawat inap di bangsal Ar-Rahman RSU PKU Muhammadiyah Bantul Yogyakarta.

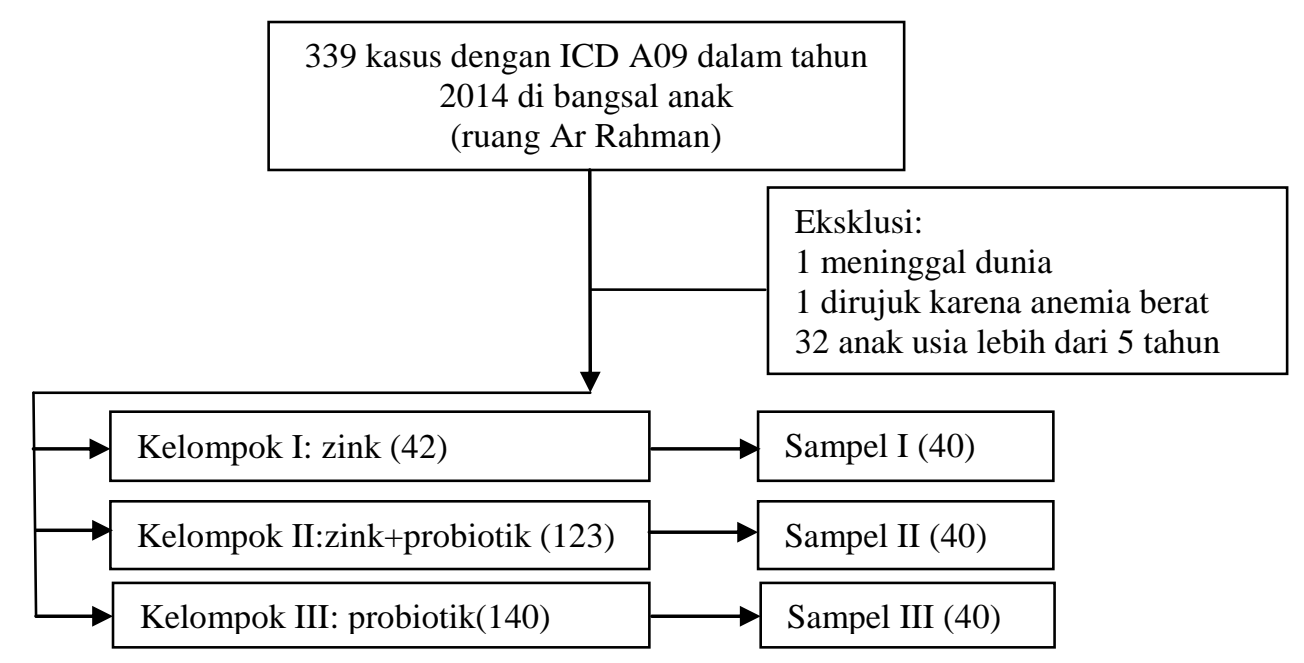

\section{Gambar 2. Alur data penelitian}

Untuk mengetahui ada tidaknya pengaruh umur, berat badan dan status nutrisi terhadap durasi diare, maka dilakukan uji statistik regresi dan korelasi. Uji analisis statistik regresi linier dan korelasi dari data umur, berat badan dan status nutrisi pada penelitian ini, tidak terdapat hubungan terhadap durasi diare nilai signifikansi lebih dari 0,05.

Tabel I. Umur dan berat badan masing-masing kelompok

\begin{tabular}{ccccc}
\hline Kelompok & Umur (bulan) & P value umur & Berat badan $(\mathrm{kg})$ & $\mathrm{P}$ value BB \\
\hline I & $22,95 \pm 16,17$ & & $11,38 \pm 4,24$ & \\
II & $20,61 \pm 13,62$ & $\mathrm{P}=0,57$ & & \\
& & & $10,78 \pm 4,88$ & $\mathrm{P}=0,66$ \\
III & $22,06 \pm 14,25$ & & $11,25 \pm 4,75$ & \\
\hline
\end{tabular}

Dari data kriteria inklusi yang terkumpul diperoleh 3 kelompok yaitu kelompok yang mendapat terapi rehidrasi oralit dan atau cairan infus dan zink 42 anak (13,8\%), kelompok yang mendapat terapi rehidrasi oralit dan atau cairan infus, zink dan probiotik 123 anak (40,3\%) dan kelompok yang mendapat terapi rehidrasi oral dan atau cairan infus dan probiotik 140 anak $(45,9 \%)$. 
Tabel II. Jumlah masing-masing kelompok dan terapinya

\begin{tabular}{ccccc}
\hline kelompok & jumlah & Rehidrasi & \multicolumn{1}{c}{ zink } & \multicolumn{1}{c}{ Probiotik } \\
\hline I & 42 & $75 \mathrm{cc} / \mathrm{kg} \mathrm{bb}$ & $\begin{array}{l}\text { Usia } 0-6 \text { bulan } \\
10 \mathrm{mg} / \text { hari }\end{array}$ & $\begin{array}{c}\text { Usia } 0-6 \text { bulan } 2 \mathrm{x} \\
\text { sehari 1/2 sachet }\end{array}$ \\
II & 123 & $75 \mathrm{cc} / \mathrm{kg} \mathrm{bb}$ & $\begin{array}{l}\text { Usia }>6 \text { bulan } \\
20 \mathrm{mg} / \text { hari }\end{array}$ & $\begin{array}{c}\text { Usia }>6 \text { bulan } 2 \\
\text { x sehari 1 sachet }\end{array}$ \\
III & 140 & $75 \mathrm{cc} / \mathrm{kg} \mathrm{bb}$ & & \\
\hline Total & 305 & & & \\
\hline
\end{tabular}

Tabel III. Durasi diare kelompok I, II dan III dan hasil statistik anova

\begin{tabular}{cccc}
\hline kelompok & Terapi & Durasi diare (jam) & P value \\
\hline I & Rehidrasi+zink & $66,33($ SD 21,66) & \\
II & Rehidrasi +zink + probiotik & $55,32($ SD 19,07) & \multirow{2}{*}{0,014} \\
III & Rehidrasi + probiotik & $54,79($ SD 17,69) & \\
\hline
\end{tabular}

Terdapat perbedaan yang bermakna antar varian dari 3 kelompok, maka uji statistik dilanjutkan dengan $t$ test untuk mengetahui perbedaan yang bermakna dari masing-masing kelompok. Hasil uji $t$ test kelompok I terhadap kelompok II terdapat perbedaan yang bermakna $(p=0,018)$. Hasil uji $t$ test kelompok I terhadap kelompok III terdapat perbedaan yang bermakna $(\mathrm{p}=0,011)$. Hasil uji $\mathrm{t}$ test kelompok II terhadap kelompok III tidak berbeda bermakna $(\mathrm{p}=0,898)$.

Tujuan pertama dalam penelitian ini adalah untuk mengetahui gambaran pemberian pola terapi yang diberikan untuk diare pada anak. Dalam penelitian ini diperoleh gambaran bahwa anak-anak yang menderita diare dalam tahun 2014 sebanyak 339 anak, semuanya mendapatkan terapi rehidrasi menggunakan oralit dan atau cairan infus kristaloid sebagai terapi yang utama (100\%), suplementasi zink dan atau probiotik. Dari keseluruhan penderita diare 90\% (305 anak) adalah usia dibawah 5 tahun. Menurut WHO diare merupakan penyebab utama kedua pada anak usia dibawah 5 tahun di seluruh dunia. Rekomendasi terapi pada diare dari WHO adalah rehidrasi sedini mungkin dengan ORS (Oral Rehidration Salt) atau oralit di Indonesia dengan suplementasi zink. Oleh sebab itu, rehidrasi dan zink pada penelitian ini digunakan sebagai kelompok kontrol standar WHO. Dosis zink yang digunakan adalah $10 \mathrm{mg}$ per hari untuk anak usia 0-6 bulan, dan $20 \mathrm{mg}$ per hari untuk anak usia di atas 6 bulan. Penggunaan zink untuk diare pada anak diatas 5 tahun tidak efektif (Negi et.al., 2014). Oleh karena rehidrasi dan zink adalah kontrol, sedangkan zink tidak efektif pada anak usia diatas 5 tahun, maka kriteria inklusi dalam penelitian ini adalah anak di bawah 5 tahun.

Tujuan penelitian yang kedua adalah untuk mengetahui efektifitas pemberian probiotik pada diare anak. Dosis probiotik yang digunakan adalah 2 kali sehari $1 / 2$ sachet untuk usia 0-6 bulan dan 2 kali sehari 1 sachet untuk usia diatas 6 bulan. Probiotik yang digunakan berisi probioik hidup strain Lactobacillus acidophilus, Bifidobacterium longun, Streptococcus thermophilus 1 × $10^{7}$. Penggunaan zink dan atau probiotik sebagai terapi tambahan pada pasien diare anak di RSU PKU Muhammadiyah Bantul perincianya adalah sebagai berikut: yang mendapat suplementasi zink saja $13,8 \%$, yang mendapat suplementasi zink plus probiotik $40,3 \%$, dan yang mendapat suplementasi probiotik sebanyak 45,9\%. Dari uji statistik anova dan dilanjutkan uji statistik t test diperoleh hasil ada perbedaan yang bermakna $(\mathrm{p}=0,014)$ antara kelompok kontrol (kelompok I) dan kelompok probiotik (kelompok II dan kelompok III). Hal ini senada dengan penelitian (Randomized Clinical Trial) yang telah banyak dilakukan bahwa probiotik mempunyai efektifitas menurunkan durasi diare akut pada anak-anak (Hatta et.al., 2011).

Menurut (Azim et.al., 2014), dibandingkan dengan menggunakan terapi rehidrasi saja, penambahan probiotik dapat menurunkan durasi diare. Pengamatan selama 5 hari menunjukkan bahwa efektifitas probiotik meningkat pada penggunaan 2 hari sejak onset diare dan frekwensi diare 2 kali lebih sedikit dibanding kontrol dalam 3 hari. Senada dengan penelitian (Alasiry et.al., 2007) yang menyatakan bahwa penurunan lama diare dan frekwensi diare perhari dimulai hari kedua setelah 
pemberian probiotik, berat badan juga meningkat secara signifikan. Penelitian prospektif yang mirip variable penelitianya dengan penelitian ini adalah penelitian (Hatta et.al., 2011; Aggarwal et.al., 2014), dimana keduanya menggunakan kontrol terapi rehidrasi dan zink, sesuai standar WHO. Penambahan probiotik menyebabkan penurunan durasi diare yang signifikan disbanding kelompok yang menggunakan rehidrasi dan suplemen zink saja.

Pada penelitian ini, data jumlah cairan yang dikonsumsi baik per oral maupun intra vena tidak diteliti. Pemberian cairan rehidrasi pada diare menurunkan angka kematian melalui cara mencegah dan mengatasi dehidrasinya, tetapi tidak menurunkan durasi diare dan jumlah feses (Bhatnagar et.al., 2004). Informasi status nutrisi dalam rekam medis didapatkan dari keterangan asuhan gizi, tanpa ada pengamatan dari penulis. Dari keseluruhan populasi criteria inklusi, ada $2 \%$ anak yang mengalami gizi kurang dan mendapat asuhan nutrisi dari bagian gizi rumah sakit. Status nutrisi mempengaruhi penurunan durasi diare oleh probiotik pada hewan percobaan. Penurunan durasi diare terjadi karena adanya respon host terhadap bakteri baik dan pathogen yang dipengaruhi status nutrisi (Preidis et.al., 2012). Pada penelitian durasi diare anak, status nutrisi bisa menjadi faktor perancu karena status nutrisi mempengaruhi durasi diare dan juga dapat mempengaruhi efektifitas probiotik dalam meningkatkan respon imunitas. Keseragaman berat badan dan umur rata-rata pada tiap-tiap kelompok diharapkan tidak menyebabkan status nutrisi menjadi faktor perancu yang berarti pada penelitian ini.

Penulis menyadari bahwa penelitian ini mempunyai beberapa kelemahan yaitu tidak adanya data frekwensi diare dan konsistensi feses sebagai outcome pengamatan penelitian. Jumlah cairan yang dikonsumsi selama perawatan dan status nutrisi yang tidak teramati pada penelitian ini, hanya melalui data umur dan berat badan anak dari rekam medis saja.

\section{KESIMPULAN}

Pola terapi diare pada RSU PKU Muhammadyah Bantul Yogyakarta terbagi menjadi 3 macam terapi utama.Yang pertama terapi rehidrasi dan suplementasi zink, kedua terapi rehidrasi dan suplementasi zink dan probiotik, yang ketiga adalah terapi rehidrasi dan suplementasi probiotik. Suplementasi probiotik terbukti efektif $(55,32 \pm 19,07$ jam dan 54,79 $\pm 17,69$ jam) mengurangi durasi diare secara bermakna dibandingkan pasien yang mendapatkan terapi standar rehidrasi dan zink saja $(66,33 \pm 21,66$ jam $)$ dengan nilai $\mathrm{p}=0,014$.

\section{UCAPAN TERIMA KASIH}

Penulis mengucapkan terima kasih kepada Bagian Diklat RSU PKU Muhammadiyah Bantul yang telah memberi ijin untuk penelitian ini.

\section{DAFTAR PUSTAKA}

Aggarwal, S., Upadhyay, A., Shah, D., Teotia, N., Agarwal, A. \& Jaiswal, V. 2014, Lactobacillus Gg For Treatment Of Acute Childhood Diarrhoea: An Open Labelled, Randomized Controlled Trial. The Indian Journal Of Medical Research, 139; 3; 379-385.

Alasiry, E., Abbas, N. \& Daud, D.2007. Khasiat Klinik Pemberian Probiotik Pada Diare Akut Non Spesifik Bayi Dan Anak. Sari Pediatri, 8; 3; 36-41.

Anonim, 2011, Buku Saku Lintas Diare, Direktorat Jendral Pengendalian Penyakit Dan Penyehatan Lingkungan. Depkes, R. I., Jakarta

Anonim,2014a, Narasi Profil Kesehatan, 2014, Din. Kes. Kab. Bantul, Bantul, Yogyakarta, hal:13-15. Anonim, 2014b, Data Base Rumah Sakit RSU PKU Muhammadiyah Bantul Tahun 2014, Bantul, Yogyakarta.

Azim, K., Sheikh, T. S. \& Khan, S. N.2014, Efficacy Of Probiotics (Sacchromyces bulardii) In Acute Watery Diarrhoea In Children. Journal Of Rawalpindi Medical College (JRMC), 18; 2; 213215.

Bhatnagar, S., Bahl, R., Sharma, P. K., Kumar, G. T., Saxena, S. K. \& Bhan, M. K. 2004, Zinc With Oral Rehydration Therapy Reduces Stool Output And Duration Of Diarrhea In Hospitalized Children: A Randomized Controlled Trial. Journal Of Pediatric Gastroenterology And Nutrition, 38; 1; 34-40. 
Dean, A. G., Sullivan, K. M. \& Soe, M. M.2011,Openepi: Open Source Epidemiologic Statistics For Public Health, Version 2.3. 1.

Hatta, M., Supriatmo, M. A., Sinuhaji, A. B., Hasibuan, B. \& Nasution, F. L.2011, Comparison Of Zinc-Probiotic Combination Therapy To Zinc Therapy Alone In Reducing The Severity Of Acute Diarrhea. Paediatrica Indonesiana, 51; 1; 1-6.

Negi, R., Dewan, P., Shah, D., Das, S., Bhatnagar, S. \& Gupta, P. 2014, Oral Zinc Supplements Are Ineffective For Treating Acute Dehydrating Diarrhoea In 5-12-Year-Olds. Acta Paediatrica, $106 ; 6$.

Penders, J., Thijs, C., Vink, C., Stelma, F. F., Snijders, B., Kummeling, I., Van Den Brandt, P. A. \& Stobberingh, E. E. 2006, Factors Influencing The Composition Of The Intestinal Microbiota In Early Infancy. Pediatrics, 118; 2; 511-521

Preidis, G. A., Saulnier, D. M., Blutt, S. E., Mistretta, T.-A., Riehle, K. P., Major, A. M., Venable, S. F., Barrish, J. P., Finegold, M. J. \& Petrosino, J. F. 2012, Host Response To Probiotics Determined By Nutritional Status Of Rotavirus-Infected Neonatal Mice. Journal Of Pediatric Gastroenterology And Nutrition, 55; 3; 299-307.

UNICEF. 2014,Current Status + Progress, Diarrhoea Remains A Leading Killer Of Young Children, Despite The Availability Of A Simple Treatment Solution, Updated: Nov 2014 Ed.Diakses pada tanggal 13 Maret 2015, http://data.unicef.org/child-health/diarrhoeal-disease.

WGO.2008, World Gastroenterology Organisation Practice Guideline Probiotics and Prebiotics. Diakses tanggal 14 Maret 2015

WGO.2012,World Gastroenterology Organisation Practice Guideline: Acute diarrhea. Diakses tanggal 26 April 2015.

WHO.2004,Joint statement Clinical Management Of Acute Diarrhea. IN WHO/UNICEF. Diakses tanggal 13 Maret 2015.

WHO.2013,Diarrhoeal Diseases, diakses $13 \quad$ Maret 2015. http://www.who.int/mediacentre/factsheets/fs330/en/ 
